\title{
Hubungan Kepadatan Bulu Babi (Echinoidea) dan Tutupan Terumbu Karang pada Kawasan Intertidal Pantai Sanur
}

\author{
Tiara Permata Sari ${ }^{\text {a*}}$, Abd Rahman As-syakur a, Yulianto Suteja a, Dwi Budi Wiyanto a \\ a Program Studi Ilmu Kelautan, Fakultas Kelautan dan Perikanan, Universitas Udayana, Kampus UNUD Bukit Jimbaran, Bali 80361, Indonesia \\ *Penulis koresponden. Tel.: +62-822-477-900-52 \\ Alamat e-mail: s.tiarapermata@gmail.com
}

Diterima (received) 12 Januari 2017; disetujui (accepted) 18 Mei 2017; tersedia secara online (available online) 20 Mei 2017

\begin{abstract}
Marine intertidal region is an area that is affected by the mainland. One of the ecosystems found in the intertidal area is the coral reef ecosystem. Urchin is one that lives on these ecosystems. Sanur Beach area has coral reefs and the intertidal zone is quite extensive. The many activities and cruise tourism in Sanur Beach will indirectly affect the life of coral reefs and associated animal in it in this case urchins. The purpose of this study was to determine the relationship density of sea urchins and coral reefs cover percentage in the intertidal area on Sanur Beach. Research done during low tide. Coral reef data collection method and the density of sea urchins using $5 \times 5 \mathrm{~m}$ quadratic transects were analyzed using Pear Person bivariate correlations. Urchin densities ranging between $0-2.04$ ind $/ \mathrm{m}^{2}$. The percentage cover coral reefs ranged from $0.1-17.9 \%$. High and low density of sea urchins and the percentage of coral reefs affected allegedly incompatibility place their lives and because of pressure from community activities in Sanur. The density of sea urchins and the percentage of coral cover has a significant relationship with a strong degree of correlation is 0.79 . Positive direction on that relationship means that the higher percentage of coral reefs, the higher density of sea urchins. This assume in which they live almost the same that is in need of a hard substrate and urchins use of coral reefs as a shelter.
\end{abstract}

Keywords:sea urchin; coral reef; correlation; Sanur Beach

\begin{abstract}
Abstrak
Kawasan intertidal merupakan daerah laut yang dipengaruhi oleh daratan. Salah satu ekosistem yang terdapat di kawasan intertidal adalah ekosistem terumbu karang. Bulu babi merupakan salah satu yang hidup pada ekosistem tersebut. Kawasan Pantai Sanur memiliki ekosistem terumbu karang dan juga zona intertidal yang cukup luas. Banyaknya aktivitas pariwisata dan pelayaran di Pantai Sanur secara tidak langsung akan mempengaruhi kehidupan terumbu karang dan hewan yang berasosiasi di dalamnya dalam hal ini adalah bulu babi. Tujuan dari penelitian ini adalah mengetahui hubungan kepadatan bulu babi dan persentase tutupan terumbu karang pada kawasan intertidal di Pantai Sanur. Penelitian dilakukan saat air laut sedang surut. Metode pengambilan data terumbu karang dan kepadatan bulu babi menggunakan transek kuadrat 5x5m kemudian dianalisa menggunakan korelasi bivariat Pear Person. Kepadatan bulu babi berkisar antara 0 ind $/ \mathrm{m}^{2}$ hingga $2.04 \mathrm{ind} / \mathrm{m}^{2}$. Persentase penutupan terumbu karang berkisar antara $0.1 \%$ hingga 17,9\%. Tinggi rendahnya kepadatan bulu babi dan persentase terumbu karang diduga dipengaruhi oleh ketidaksesuaian tempat hidup mereka dan diduga karena adanya tekanan dari aktivitas masyarakat di Pantai Sanur. Kepadatan bulu babi dan persentase tutupan terumbu karang memiliki tingkat korelasi yang kuat yaitu 0.79. Arah hubungan yang positif berarti semakin tinggi persentase terumbu karang maka semakin tinggi kepadatan bulu babi. Hal ini terjadi diduga tempat hidup mereka yang hampir sama yaitu membutuhkan substrat keras dan bulu babi menggunakan terumbu karang sebagai tempat berlindung
\end{abstract}

Kata Kunci:bulu babi; terumbu karang; korelasi; Pantai Sanur 


\section{Pendahuluan}

Bulu babi (Echinoidea) merupakan kelompok hewan lunak yang memiliki cangkang, dan tidak memiliki tulang belakang atau Avertebrata (Radjab dkk., 2010). Menurut Purwandatama (2014), bulu babi merupakan spesies kunci (keystone species) bagi komunitas terumbu karang, menurunnya populasi bulu babi diduga akan menyebabkan matinya terumbu karang karena populasi makroalga akan meningkat dengan drastis sehingga makrolaga akan menutupi terumbu karang. Selain itu, bulu babi juga telah digunakan sebagai bioindikator pencemaran laut (Rumahlatu, 2012).

Kawasan intertidal merupakan daerah laut yang dipengaruhi oleh daratan. Zona ini memiliki faktor fisik maupun kimia yang mendukung semua organisme didalamnya untuk dapat tumbuh dan berkembang dengan baik. Zona ini luasnya sangat terbatas, tetapi banyak terdapat variasi faktor lingkungan yang terbesar dibandingkan dengan daerah lautan lainnya. Oleh karena itu keanekaragaman organismenya sangat besar (Katili, 2011). Salah satu ekosistem yang terdapat di kawasan intertidal adalah ekosistem terumbu karang.

Terumbu karang memiliki nilai penting bagi bagi biota laut tropis sehingga terumbu karang memiliki keanekaragaman jenis biota yang sangat tinggi dan sangat produktif (Amin, 2009). Bulu babi merupakan salah satu biota laut dari kelas Echinodea dari filum Echinodermata yang dapat ditemui pada daerah terumbu karang. Pada terumbu karang, kelompok biota ini dapat ditemukan pada berbagai habitat seperti zona rataan terumbu, daerah pertumbuhan algae, padang lamun, koloni karang hidup, koloni karang mati dan beting karang (rubbles and boulders) (Thamrin et al., 2011).

Penelitian mengenai bulu babi sudah beberapakali dilakukan di Provinsi Bali, antara lain studi mengenai densitas bulu babi di Pantai Serangan dan Pantai Sanur dengan hasil paling tinggi terdapat di Pantai Serangan yaitu 0,373 ind $/ \mathrm{m}^{2}$ dan densitas terendah di Pantai Mertasari yaitu 0,144 ind $/ \mathrm{m}^{2}$ (Wulandewi et al., 2015); Keanekaragaman dan dominansi bulu babi di Pulau Menjangan oleh Yudasmara (2013). Namun, studi mengenai hubungan kepadatan bulu babi dan terumbu karang hidup belum pernah dilakukan di Pantai Sanur. Kawasan Pantai Sanur memiliki zona intertidal yang cukup luas dan di dalamnya terdapat ekosistem terumbu karang. Kawasan pantai ini dimanfaatkan sebagai obyek pariwisata yang lengkap dengan berbagi fasilitias penunjang pariwisata seperti penginapan, hotel, restaurant, dan tempat untuk aktivitas pelayaran. Hal tersebut secara tidak langsung akan mempengaruhi kehidupan terumbu karang dan hewan yang berasosiasi di dalamnya dalam hal ini adalah bulu babi. Sehinggaa, penelitian ini penting dilakukan untuk mengetahui hubungan kepadatan bulu babi yang hidup dalam ekosistem terumbu karang pada kawasan intertidal di Pantai Sanur yang padat akan aktivitas antropogenik.

\section{Metode Penelitian}

\subsection{Waktu dan Tempat}

Penelitian dilakukan selama bulan Maret 2016 saat air laut sedang surut. Penelitian ini dilakukan pada kawasan intertidal di Pantai Sanur. Peta lokasi penelitian terlihat pada Gambar 1. Peta lokasi dibuat dengan tujuan untuk menegaskan letak stasiun yang diambil secara random sampling tanpa memperhatikan perbedaan karakteristik tempat.

\subsection{Alat Penelitian}

Tabel 1

Peralatan penelitian hubungan kepadatan bulu babi dan persentase penutupan terumbu karang pada kawasan intertidal di Pantai Sanur.

\begin{tabular}{lll}
\hline Nama alat & Spesifikasi & \multicolumn{1}{c}{ Kegunaan } \\
\hline GPS & Garmin 78s & Untuk plot lokasi \\
Kamera & Samsung & Mendokumentasikan \\
& Grand Prime & penelitian \\
& 8MP & \\
Kertas & Kertas anti & Mencatat data \\
newtop & air & penelitian \\
dan pensil & & \\
Masker & Scuba Pro & Untuk melihat biota \\
selam & & \\
Microsoft & Windows & Untuk menganalisa \\
excel & & data \\
Stick & Besibaja 30 & Untuk mencari bulu \\
& cm & babi \\
Transek & Tali rafia & Sebagai pembatas \\
kuadrat & dan paku & sample penelitian \\
\hline
\end{tabular}



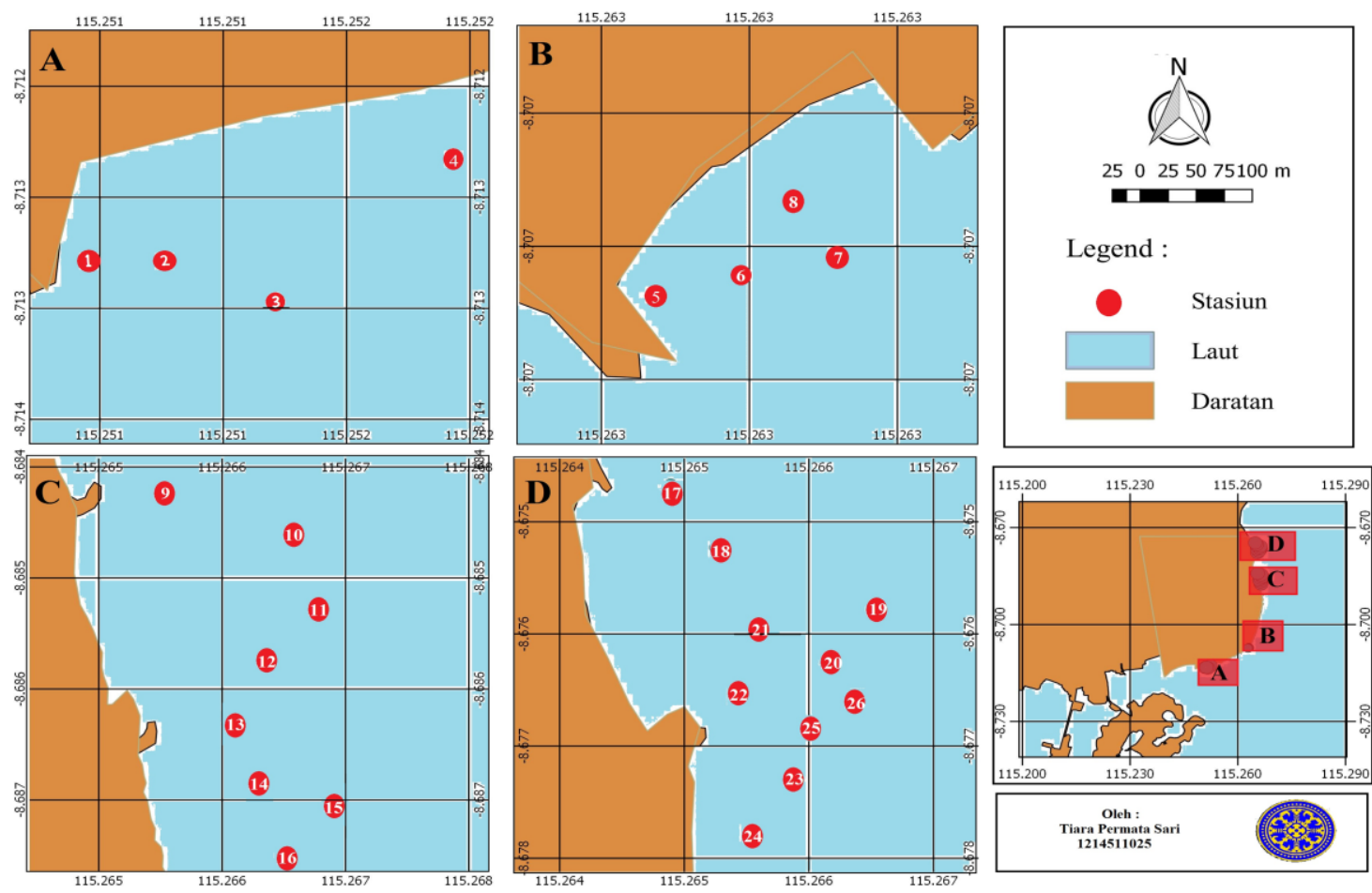

Gambar 1. Peta lokasi penelitian. Titik merah menunjukan lokasi pengambilan sampel dan nomor mengindikasikan nomor sampel.

\subsection{Metode Penelitian}

2.3.1. Metode penelitian persentase tutupan terumbu karang

Metode yang digunakan menggunkan metode transek kuadrat ukuran $5 \times 5 \mathrm{~m}$ dan di dalamnya dibagi lagi menjadi 25 sub-plot transek. Dalam pengamatan persentase penutupan terumbu karang pengisian data langsung menggunkan persentase. Hasil persentase tersebut selanjutnya di interpretasikan sesuai tabel kondisi terumbu karang (Tabel 2).

\subsubsection{Metode penelitian kepadatan bulu babi}

Pengambilan data bulu babi dilakukan bersamaan dengan pengambilan data persentase terumbu karang. Perhitungan kepadatan bulu babi menggunakan rumus menurut Pratiwi dan Ernawati (2016) sebagai berikut :

$K=\frac{n i}{L}$

dimana $K$ adalah kepadatan bulu babi. $n i$ adalah total individu. $L$ adalah Luas transek pengamatan.
Tabel 2

Kriteria presentase penutupan terumbu karang (UNEP, 1993).

\begin{tabular}{ccc}
\hline Kategori & $\begin{array}{c}\text { Persentase penutupan } \\
\text { terumbu karang } \\
\text { hidup(\%) }\end{array}$ & Kriteria \\
\hline 1 & $0-10$ & Sangat rendah \\
2 & $11-30$ & Rendah \\
3 & $31-50$ & Sedang \\
4 & $51-75$ & Tinggi \\
5 & $76-100$ & Sangat tinggi \\
\hline
\end{tabular}

\subsection{Analisa Data}

Analisa data antara korelasi kepadatan bulu babi dan persentase tutupan terumbu karang menggunakan analisa korelasi Pear Pearson. Rumus yang digunakan adalah sebagai berikut :

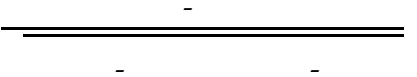

dimana $\mathrm{r}_{\mathrm{xy}}$ adalah korelasi pearson. $\mathrm{N}$ adalah jumlah sampel. $\mathrm{X}$ merupakan variabel bebas, dalam penelitian ini adalah persentase penutupan terumbu karang. Y merupakan variabel terikat, dalam penelitian ini adalah kepadatan bulu babi. 


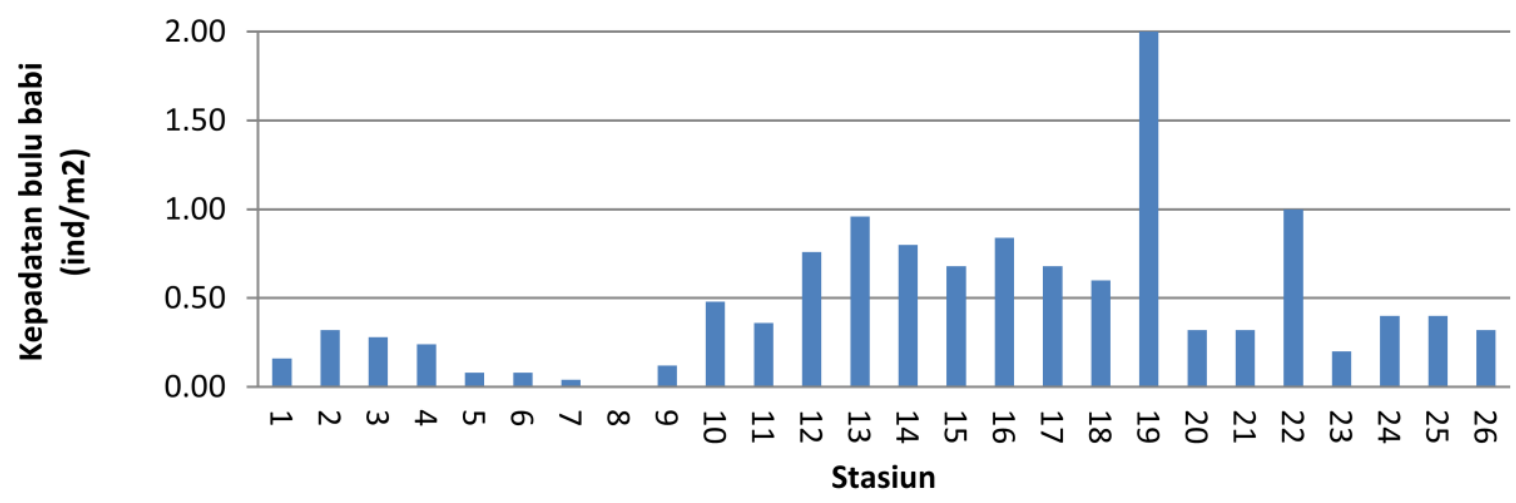

Gambar 2. Kepadatan bulu babi

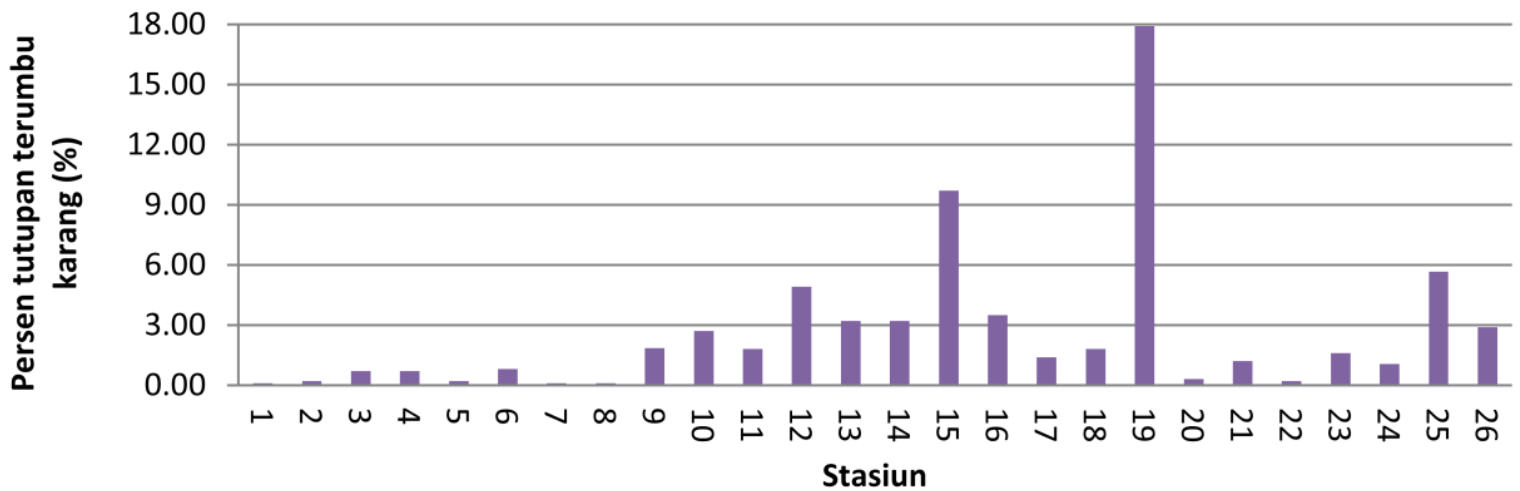

Gambar 3. Grafik Persentase tutupan terumbu karang

Hasil analisa korelasi pearson antara kepadatan bulu babi dan persentase tutupan terumbu karang akan dilihat kekuatan hubunganya seperti terlihat pada Tabel 3, jika dilihat secara garis besar terlihat semakin nilai korelasinya mendekati 0 maka hasil korelasinya semakin lemah, sebaliknya jika semakin mendekati angka 1 maka hasil korelasinya semakin kuat.

\section{Hasil}

\subsection{Kepadatan Bulu Babi}

Berdasarkan hasil pengumpulan data 26 stasiun bulu babi pada kawasan intertidal di Pantai Sanur, jumlah individu bulu babi yang ditemukan yaitu sebanyak 0 hingga 51 individu pada tiap stasiun. Dari hasil tersebut didapatkan hasil kepadatan bulu babi pada kawasan intertidal di Pantai Sanur berkisar antara 0 ind $/ \mathrm{m}^{2}$ hingga $2.04 \mathrm{ind} / \mathrm{m}^{2}$. Kepadatan bulu babi terendah terdapat pada stasiun-8 dan kepadatan tertinggi terdapat pada stasiun-19. Hasil rata-rata kepadatan bulu babi pada kawasan intertidal di Pantai Sanur ini 0.48 ind $/ \mathrm{m}^{2}$. Grafik hasil pengamatan terhadap kepadatan bulu babi dapat terlihat pada Gambar 2 .

Tabel 3

Kriteria presentase penutupan terumbu karang (Sugiyono, 2007).

\begin{tabular}{cc}
\hline Angka Interprestasi & Hubungan Korelasi \\
\hline $0-0.1999$ & Sangat lemah \\
$0.20-0.399$ & Lemah \\
$0.40-0.599$ & Sedang \\
$0.60-0.799$ & Kuat \\
$0.80-1.0$ & Sangat kuat \\
\hline
\end{tabular}

\subsection{Persentase Tutupan Terumbu Karang}

Hasil penelitian terhadap persentase penutupan terumbu karang hidup pada kawasan intertidal di Pantai Sanur di 26 stasiun yang berbeda yaitu berkisar antara $0.1 \%$ hingga $17,9 \%$ dengan ratarata persentase penutupan terumbu karang hidup pada kawasan intertidal di Pantai Sanur adalah $2.61 \%$. Berdasarkan rata-rata tersebut secara keseluruhan kondisi terumbu karang pada 
kawasan intertidal di Pantai Sanur masuk dalam kondisi terumbu karang yang sangat buruk. Grafik persentase tutupan terumbu karang pada kawasan intertidal di Pantai Sanur dapat terlihat pada Gambar 3.

\subsection{Korelasi Kepadatan Bulu Babi dan Persentase Penutupan Terumbu Karang Hidup}

Hasil analisa korelasi menggunakan korelasi bivariat Pear Person antara kepadatan bulu babi dan persentase penutupan terumbu karang menunjukkan angka korelasi Pearson sebesar 0.79 dan korelasi tersebut memiliki nilai signifikansi 0.01. Arah korelasi dilihat dari angka koefisien korelasi hasilnya positif atau negatif, karena angka koefesien korelasi hasilnya positif, yaitu 0,79 , maka korelasi kedua variabel bersifat searah.

\section{Pembahasan}

Pengamatan hubungan kepadatan bulu babi dan persentase penutupan terumbu karang pada kawasan intertidal di Pantai Sanur dimulai dari Pantai Mertasari hingga Pantai Sanur. Berdasarkan pengamatan di lapangan, stasiun-1 hingga stasiun9 memiliki nilai kepadatan yang lebih rendah. Pada lokasi ini jarang ditemukan batuan, banyak terdapat pecahan karang (rubble) dan juga pasir. Diduga kondisi tersebut kurang sesuai dengan tempat hidup bulu babi karena meskipun terdapat banyak rubble namun jarang ditemukan batuan sebagai tempat berlindung bulu babi dari predatornya. Hal ini dikemukakan oleh Rahim et al. (2016) menyatakan bahwa, lokasi habitat bulu babi seperti tersedianya tempat berlindung bulu babi dari predatornya memberikan peranan penting bagi kelangsungan hidup bulu babi yang dapat mempengaruhi distribusi dan kepadatan bulu bab

Rendahnya kepadatan bulu babi pada stasiun- 5 sampai stasiun-9 diduga dipengaruhi oleh padatnya aktivitas masyarakat seperti penambatan jangkar kapal ataupun boat, dan juga tempat lalu lalang perahu-perahu nelayan. Menurut penelitian Wulandewi (2015), tingginya aktivitas masyarakat di sekitar pantai akan mempengaruhi habitat bulu babi dan secara tidak langsung akan mempengaruhi kepadatan bulu babi.

Pada stasiun-10 sampai stasiun-26 lebih banyak ditemui batuan dan lebih sering dijumpai karang mati yang ditumbuhi algae. Berdasarkan pengamatan di lapangan, bulu babi lebih banyak dijumpai pada kawasan intertidal yang banyak terdapat batuan atau lubang karang mati dan karang mati yang ditumbuhi algae. Diduga kondisi tersebut sesuai dengan tempat hidup bulu babi. Adanya batuan atau lubang karang mati sebagai tempat berlindung dan algae sebagai sumber pakan. Thamrin et al. (2011) mengemukakan bahwa, ketersediaan makanan dan kehadiran predator akan menekan jumlah kehadiran bulu babi.

Kepadatan bulu babi tertinggi terdapat pada stasiun ke-19, lokasi pada stasiun ini berupa cekungan yang cukup lebar dengan banyak batuan dan memiliki substrat keras. Stasiun ini juga memiliki persentase tutupan terumbu karang yang paling tinggi dari 26 stasiun yang diamati meski masih dalam kategori yang rendah. Banyak bulu babi yang bersembunyi pada lubang-lubang yang ada pada batu tersebut. Letak stasiun ini lebih menjorok kearah laut. Diduga hal tersebut menyebabkan pada stasiun ini memiliki kepadatan yang lebih tinggi karena tempat hidup yang sesuai dan lebih jauh dari jangkauan masyarakat serta wisatawan yang berkunjung di pantai. Menurut penelitian mengenai jenis dan densitas bulu babi yang ada di Pulau Menjangan oleh Yudasmara (2013), kebanyakan bulu babi hidup pada substrat yang keras, yakni batu-batuan atau terumbu karang dan hanya sebagian kecil yang menghuni substrat pasir dan lumpur karena pada kondisi demikian kaki tabung sulit untuk mendapatkan tempat melekat. Disamping itu, kepadatan yang rendah atau kecil tersebut diduga disebabkan oleh ketidakmampuan individu untuk menempati habitat dan juga disebabkan karena bulu babi mengalami gangguan dari aktifitas penduduk.

Rata-rata kepadatan bulu babi yang hidup di daerah terumbu karang pada kawasan intertidal Pantai Sanur lebih rendah bila dibandingkan dengan kepadatan bulu babi yang berada di Pulau Mapur yang mencapai 21,11 ind $/ \mathrm{m}^{2}$ (Thamrin et al., 2011). Hal tersebut terjadi diduga karena bulu babi yang hidup di Pulau Mapur memiliki habitat terumbu karang dalam kondisi baik. Berbeda dengan terumbu karang pada kawasan intertidal di Pantai Sanur yang kondisi terumbu karangnya sangat buruk. Menurut penelitian yang dilakukan oleh Thamrin et al (2011), kepadatan bulu babi lebih banyak ditemukan pada kondisi terumbu karang kategori rendah sampai sedang, sedangkan pada kondisi terumbu karang yang sangat buruk, 
baik dan, sangat baik kepadatan bulu babi akan sangat berkurang.

Persentase penutupan karang hidup terendah ada di tiga stasiun yaitu stasiun ke-1, ke-7, dan ke8. Stasiun ini merupakan stasiun yang jarang ditemukan batuan, lebih banyak ditemukan patahan dari karang bercabang. Stasiun tersebut juga padat akan aktivitas manusia karena pada stasiun tersebut digunakan sebagai tempat berlabuhnya kapal atau boat. Jangkar yang ditambatkan pada lokasi tersebut dapat merusak ekosistem terumbu karang dan secara tidak langsung akan mempengaruhi kepadatan bulu babi. Pada penelitian yang dilakukan oleh Yudasmara (2013) di Pulau Menjangan menyebutkan bahwa lokasi dimana terdapat dermaga tempat untuk bersandarnya kapal boat juga ikut mempengaruhi persentase tutupan karang hidup sehingga mempengaruhi kehadiran bulu babi disana.

Persentase penutupan karang hidup tertinggi berada pada stasiun-19 dengan kategori rendah. Stasiun ini letaknya lebih menjorok ke laut. Diduga hal tersebut mempengaruhi lebih banyaknya persentase penutupan karang hidup karena jauh dari jangkauan masyarakat maupun wisatawan. Hal ini seperti di uraikan oleh Subhan dkk. (2014) bahwa, salah satu penyebab kerusakan terumbu karang adalah diakibatkan oleh adanya kegiatan manusia yang secara langsung maupun tidak langsung merusak terumbu karang, seperti penangkapan ikan yang tidak ramah lingkungan seperti dengan bahan peledak dan bahan beracun, penggalian karang untuk batu kapur dan limbah beracun yang masuk ke perairan, juga adanya kegiatan wisata pantai.

Dilihat dari hasil rata-rata keseluruhan persentase tutupan karang hidup pada kawasan intertidal di Pantai Sanur masuk dalam kondisi yang sangat buruk. Diduga hal ini disebabkan kawasan Pantai Sanur sangat padat dengan aktivitas manusia. Sebagaimana yang dikenal hingga saat ini kawasan Pantai Sanur merupakan daerah pariwisata yang disekitarnya telah berkembang hotel-hotel dan sarana prasarana untuk menunjang pariwisata lainnya. Selain itu, di beberapa sisi Pantai Sanur juga dijadikan tempat berlabuhnya boat maupun kapal nelayan. Hal ini dijelaskan oleh Prasetia (2012), ekosistem terumbu karang yang ada di wilayah Asia Tenggara merupakan yang paling terancam di dunia. Besarnya ketergantungan manusia terhadap sumberdaya laut di seluruh Asia Tenggara telah menyebabkan eksploitasi yang berlebih sehingga banyak terumbu karang yang terdegradasi, khususnya di dekat pusat kepadatan penduduk.

Hasil analisa korelasi antara kepadatan bulu babi dan terumbu karang dapat disimpulkan bahwa,terdapat korelasi positif yang kuat antara kepadatan bulu babi dan terumbu karang pada kawasan intertidal di Pantai Sanur. Disetiap penambahan jumlah persentase tutupan terumbu karang pada kawasan intertidal di Pantai Sanur yang saat ini dalam kondisi sangat buruk maka akan diikuti dengan penambahan jumlah kepadatan bulu babi. Hal ini diduga karena terumbu karang dapat menyediakan tempat berlindung bagi bulu babi dan juga meyediakan sumber pakan. Hasil tersebut didukung oleh pernyataan Yudasmara (2013) dalam penelitiannya mengenai keaneka-ragaman bulu babi di Pulau Menjangan bahwa, terumbu karang berperan sebagai tempat berlindung dan sumber pakan bagi fauna bulu babi.

Di lapangan, hasil dari ke-26 stasiun pengamatan tidak selalu bahwa dengan penambahan persentase penutupan karang hidup berarti akan bertambah pula kepadatan bulu babi pada stasiun tersebut. Pada stasiun-2 dimana kepadatan bulu babi lebih tinggi namun persentase penutupan karang hidup rendah. Hal ini diduga karena bulu babi menyukai kondisi terumbu karang hidup yang rendah karena dengan kondisi tersebut maka sumber pakan bagi bulu babi yaitu algae yang hidup di karang mati meningkat. Hal ini senada dengan yang diungkapkan Tamam dkk. (2011), bila kondisi terumbu karang buruk maka akan memperluas tempat bertumbuhnya algae.

Ada pula kondisi dimana persentase terumbu karang hidup lebih tinggi namun kepadatan bulu babi rendah seperti pada stasiun ke-15. Stasiun tersebut cenderung dekat dengan pinggir pantai, diduga bulu babi pada stasiun ini telah diambil oleh masyarakat maupun nelayan yang berburu bulu babi untuk di konsumsi gonadnya. Hal ini didukung oleh pernyataan Laning et al. (2014) bahwa, rendahnya komunitas bulu babi diduga dipengaruhi oleh aktivitas masyarakat, dan aktivitas nelayan.

Bulu babi merupakan salah satu komponen penting dalam hal keanekaragaman fauna di daerah terumbu karang. Hal ini diduga karena 
bulu babi merupakan penyeimbang dalam ekosistem terumbu karang. Menurut Yudasmara (2013), secara ekologi fauna bulu babi berperan sangat penting dalam ekosistem terumbu karang, terutama dalam rantai makanan (food web), karena biota tersebut umumnya sebagai pemakan detritus dan predator. Kesetimbangan populasi bulu babi akan menjaga kesetimbangan populasi alga dan karang. Kematian massal bulu babi berdampak pada penurunan drastis tutupan terumbu karang hidup.

\section{Simpulan}

Berdasarkan hasil penelitian dari 26 stasiun pada kawasan intertidal di Pantai Sanur, adapun yang dapat disimpulkan dari penelitian ini yaitu kepadatan bulu babi tertinggi terdapat pada stasiun-19 sebanyak $2.04 \mathrm{ind} / \mathrm{m}^{2}$. Kepadatan bulu babi terendah terdapat pada stasiun-8 yaitu sebanyak $0 \mathrm{ind} / \mathrm{m}^{2}$ dengan hasil rata-rata kepadatan sebesar $0.48 \mathrm{ind} / \mathrm{m}^{2}$. Tinggi -rendahnya kepadatan bulu babi pada kawasan intertidal di Pantai Sanur diduga karena ada beberapa faktor yang kurang sesuai dengan lingkungan hidup bulu babi seperti tidak adanya batuan sebagai tempat berlindung bulu babi dan juga faktor makanan yang disukai bulu babi yaitu algae. Dugaan lainnya itu karena tingginya tekanan dari masyarakat setempat yang sering mengambil bulu babi untuk dikonsumsi gonadnya.

Persentase penutupan terumbu karang hidup terbesar berada pada stasiun-19 yaitu 17,9\% masuk dalam kategori rendah. Ada tiga stasiun yang memiliki persentse tutupan terumbu karang terendah yaitu stasiun-1, stasiun-7, dan stasiun-8 dengan persentase $0.1 \%$ dan masuk pada kategori sangat rendah. Rata-rata keseluruhan keadaan terumbu karang pada kawasan intertidal di Pantai Sanur berada pada kondisi yang sangat buruk dengan hasil persentase pertumbuhan karang hidup sebesar $2.61 \%$. Tinggi rendahnya persentase penutupan terumbu karang hidup pada kawasan intertidal di Pantai Sanur diduga karena tingginya tekanan dari aktifitas masyarakat seperti pariwisata dan juga kawasan Perairan Sanur yang digunakan sebagai tempat berlayarnya boat.

Kepadatan bulu babi dan persentase tutupan terumbu karang memiliki hubungan signifikan dengan tingkat korelasi yang kuat yaitu 0.79. Arah hubungan yang positif berarti semakin tinggi persentase terumbu karang maka semakin tinggi kepadatan bulu babi. Hal ini terjadi diduga tempat hidup mereka yang hampir sama yaitu membutuhkan substrat keras dan bulu babi menggunakan terumbu karang sebagai tempat berlindung dan mencari makan.

\section{Daftar Pustaka}

Amin. (2009). Terumbu Karang; Aset Yang Terancam (Akar Masalah Dan Alternatif Solusi Penyelamatannya). Region, 1(2), 1-12.

Katili, S. A. (2011). Struktur Komunitas Echinodermata pada kawasan intertidal di Gorontalo. Fakultas MIPA. Universitas Gorontalo. Jurnal Pendidikan dan Penelitian, 8(1), 51-61.

Laning, T. H., Yusup, D. S., \& Wiryatno, J. (2014). Sebaran Bulu Babi (Echinoidea) Di Kawasan Padang Lamun Pantai Merta Segara, Sanur-Bali. Jurnal Biologi, 18(2), 41-45.

Prasetia, I. N. D. (2012). Rekrutmen Karang Di Kawasan Wisata Lovina. Jurnal Sains dan Teknologi, 1(2), 61-72.

Pratiwi, M. A., \& Ernawati, N. M. (2016). Analisis Kualitas Air dan Kepadatan Moluska pada Kawasan Ekosistem Mangrove, Nusa Lembongan. Journal of Marine and Aquatic Sciences, 2(2), 67-72.

Purwandatama, R. W., A'In, C., Suryanti, S. (2014). Kelimpahan Bulu Babi (Sea Urchin) pada Karang Massive dan Branching di Daerah Rataan dan Tubir di Legon Boyo, Pulau Karimunjawa, Taman Nasional Karimunjawa. Diponegoro journal of Maquares, 3(1), 17-26.

Rahim, S. A. K. A., \& Nurhasan, R. (2016). Status of Sea Urchin Resources in the East Coast of Borneo. Journal of Marine Biology, 2016, ID 6393902. doi:10.1155/2016/6393902

Radjab, A. W., Khouw, A. S., Mosse, J. W., \& Uneputty, P. A. (2010). Pengaruh Pemberian Pakan Terhadap Pertumbuhan dan Reproduksi Bulubabi (Tripneustes Gratilla L) Di Laboratorium. Oseanologi dan Limnologi di Indonesia, 36(2), 243-258.

Rumahlatu, D. (2012). Respons perilaku bulu babi Deadema setosum terhadap logam berat kadmium. Bumi Lestari, 12(1), 45-54.

Subhan, A., Ardhana, I. P. G., \& Wiryatno, J. (2014). Kajian Kerusakan dan Strategi Pengelolaan Terumbu Karang Di Kawasan Konservasi Laut Daerah (KKLD) Gili Sulat Dan Gili Lawang Lombok Timur Nusa Tenggara Barat. Ecotrophic: Journal of Environmental Science, 8(1), 9-16.

Sugiyono. (2007). Metode Penenlitian Administrasi. Bandung: Alfabeta.

Thamrin, T., Setiawan, Y. J., \& Siregar, S. H. (2011). Analisa Kepadatan Bulu Babi Diadema Setosum pada Kondisi Terumbu Karang Berbeda di Desa 
Mapur Kepulauan Riau. Jurnal Ilmu Lingkungan, 5(1), 45-53.

UNEP. (1993). Monitoring Coral Reefs for Global Change. Regional Seas. Reference Methods for Marine Pollution Studies No. 61. Australia: Australian Institute of Marine Science.

Wulandewi, N. L. E., Subagio, J. N., \& Wiryatno, J. (2015). Jenis dan Densitas Bulu Babi (Echinoidea) Di
Kawasan Pantai Sanur dan Serangan Denpasar - Bali. SIMBIOSIS Journal of Biological Sciences, 3(1), 269- 280.

Yudasmara, G. A. (2013). Keanekaragaman Dan Dominansi Komunitas Bulu Babi (Echinoidea) Di Perairan Pulau Menjangan Kawasan Taman Nasional Bali Barat. Jurnal Sains dan Teknologi, 2(2), 213-220.

(C) 2017 by the authors; licensee Udayana University, Indonesia. This article is an open access article distributed under the terms and conditions of the Creative Commons Attribution license (http://creativecommons.org/licenses/by/3.0/). 